\title{
The Conservation Population of Northern White-Cheeked Gibbons (Nomascus Leucogenys) In Vietnam
}

\author{
Le Thanh An \\ (Department of Agricultural and Environmental Economics, College of Economics/ Hue University, Vietnam)
}

\begin{abstract}
Northern white-cheeked gibbon (N. leucogenys/ Nomascus leucogenys) is one of 18 gibbon species with currently status of Endangered Threat in the world. Northern white-cheeked gibbon is mainly distributed in tropical Asia. In Vietnam, Nomascus lecogenys is mostly concentrated in the north of the country. In recent years, Vietnam more and more is clearly confirmed distribution of the largest population of Nomascus leucogenys. About 18 areas of Northern Vietnam with less 80 groups are recognized about surviving of the northern white-cheeked gibbons, especially the largest population of Nomascus leucogenys in Pu Mat National Park. However, Northern white-cheeked gibbon also deals with many threats and challenges in conservation and management by mainly pet trade and degradable habitats. Thus, the research refers some suggestions to conservation and management of gibbons. In the future, Vietnam, threatened problems relating to conservation of gibbons have been solved and prevented, can become the key of the natural conservation center of Nomascus leucogenys in the world.
\end{abstract}

Keywords - Vietnam, Northern white-cheeked gibbon (N. leucogenys), Gibbons, Conservation

\section{Introduction}

Gibbons (Hylobatidae), with the smallest of apes, distributed in the tropical forests of Southeast Asia. Gibbons, are currently recognized the four gibbon subgenera (Hylobates, Nomascus, Symphalangus, and Hoolock) with 18 gibbon species ([15], [31], [49]), and occupy a range stretching from northeastern India, south to Sumatra, Borneo, Java and north into the southernmost parts of China, with ranges among genera being largely separated by major rivers ([27], Fig. 1). Mostly species of the family Hylobatidae are on the brink of extinction, exception of Eastern Hoolock gibbon (Hoolock leuconedys), and are classified as "Endangered" or even "Critically Endangered" ([11], [15]). Northern white-cheeked gibbon (N. leucogenys) is, being the world's rarest primate, one of classified lists as "Critically Endangered" [15].

Northern white-cheeked gibbon belongs to the families Hylobatidae with genera of Nomascus, which has 52 chromosomes and is characterized by shorter dense hair compared to other gibbon genera ([44], [49]). The specie of Nomascus leucogenys is recognized in Vietnam, Lao PDR and southern Yunnan Province of China ([2], [13], [43], and Fig. 2). In 2008, the number of N. leucogenys is limited with a few semi-wild individual in Xishuanbanna Autonomous Prefecture of Yunnan Province, China and they are on the edge of extinction in the wild [9]. In the world, therefore, Vietnam and Lao PDR are clearly habitats for maintaining the population of $\mathrm{N}$. leucogenys in the current as well as in the future.

In Vietnam, Nomascus lecogenys is mainly distributed in the northeastern Viet Nam, which adapts to subtropical climate with a short and not very cold winter without frost, an average annual temperature of $23.6^{\circ} \mathrm{C}$ $\left(74.5^{\circ} \mathrm{F}\right)$ and average annual rainfall between 1364 and $1894 \mathrm{~mm}$, at elevations of 200-600 m [5]. In addition, recently discovery shows that the population of $\mathrm{N}$. leucogenys also occurs in the north-western part of the country and to the west of the Black River [10]; and trends to extending further south [50]. However, the population of $\mathrm{N}$. leucogenys deals with many threatens due to hunting and habitat degradation. Thus, the aim of the approach intends to review absolutely distributive population of the northern white-cheeked gibbons in Vietnam, and shows threats to conservation and management of their surviving. Hence, assessment of the population status of Northern white-cheeked gibbon has been fully significant and contributed to conservation and management of gibbons not only in Vietnam but also in the world. 


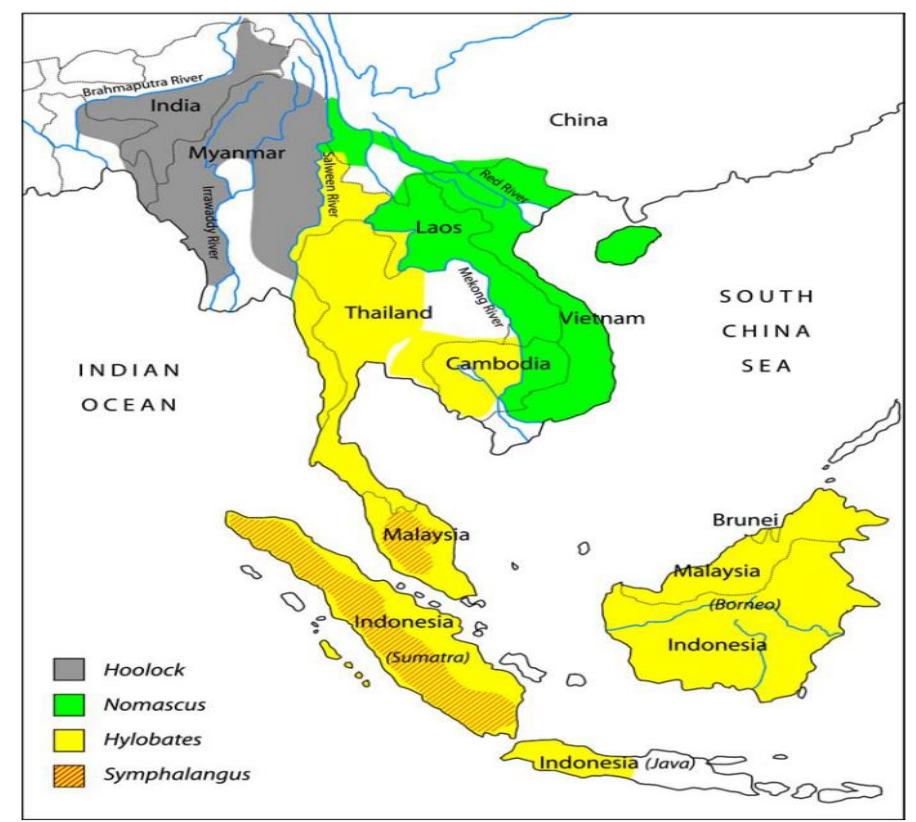

Fig. 1 Geographic distributions of the four gibbon genera [49]

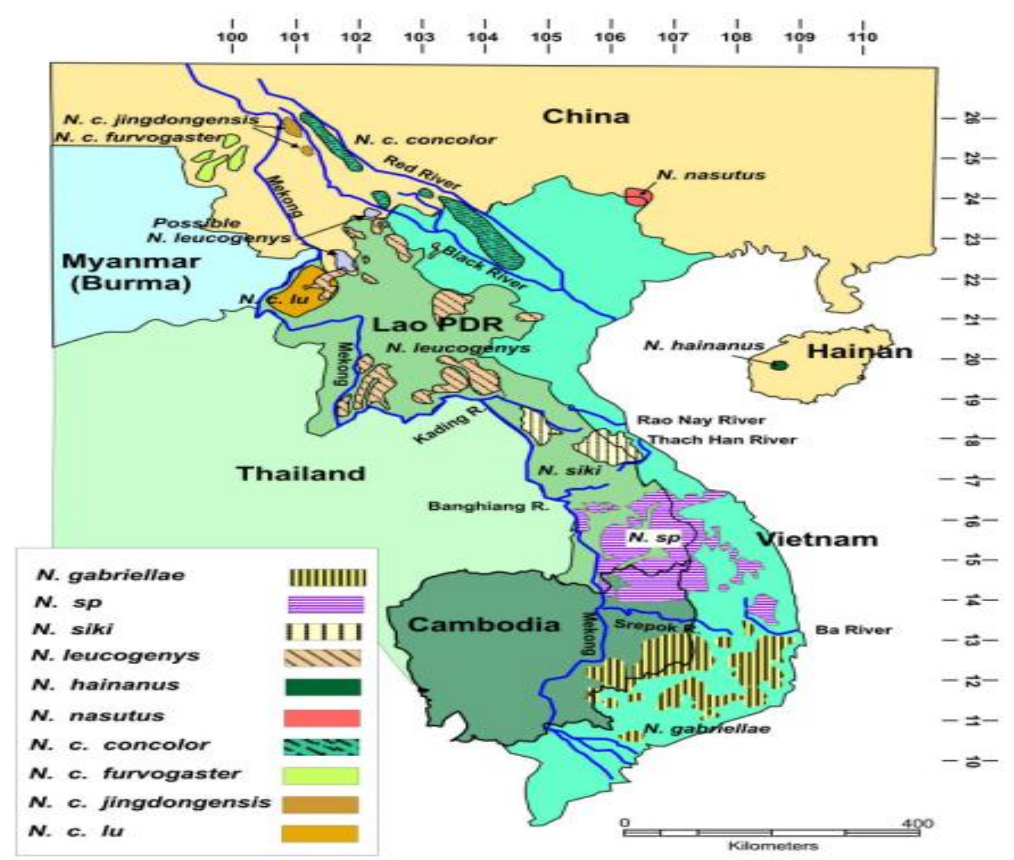

Fig. 2 Distribution of genus Nomascus spp. [32]

\section{Threat Status and Distribution of Northern White-cheeked Gibbon In Vietnam}

Vietnam is a tropical country in the Indochina Peninsula of Southeast Asia (Fig. 3). Its total land area is 33038000 ha, and its landscape includes mountains reaching 3,000 meters above sea level and two major river deltas (the Red river delta in the north and the Mekong delta in the south). The marine territory is large covering with a coastal line of $3,260 \mathrm{~km}$ and thousand of various islands. The country's climate is characterized by tropical monsoon combining with sub-tropical and temperate mountain climate. The inland has 3 climate types with 10 typical regions representing different eco-regions [30]. Thus, Vietnam has been acknowledged as a country rich in biodiversity [47], and one of the prioritized nations and hotspots for global conservation [42]. The diversity of terrain, soil, landscapes and climate are foundation for the diversity of ecosystems, species and genes. Furthermore, Vietnam is considered a nation of various and abundant natural resources, ranked $16^{\text {th }}$ worldwide of biodiversity with more than 800 different species, and is one of the world's plant breeding centers ([14], [30], [52]). 


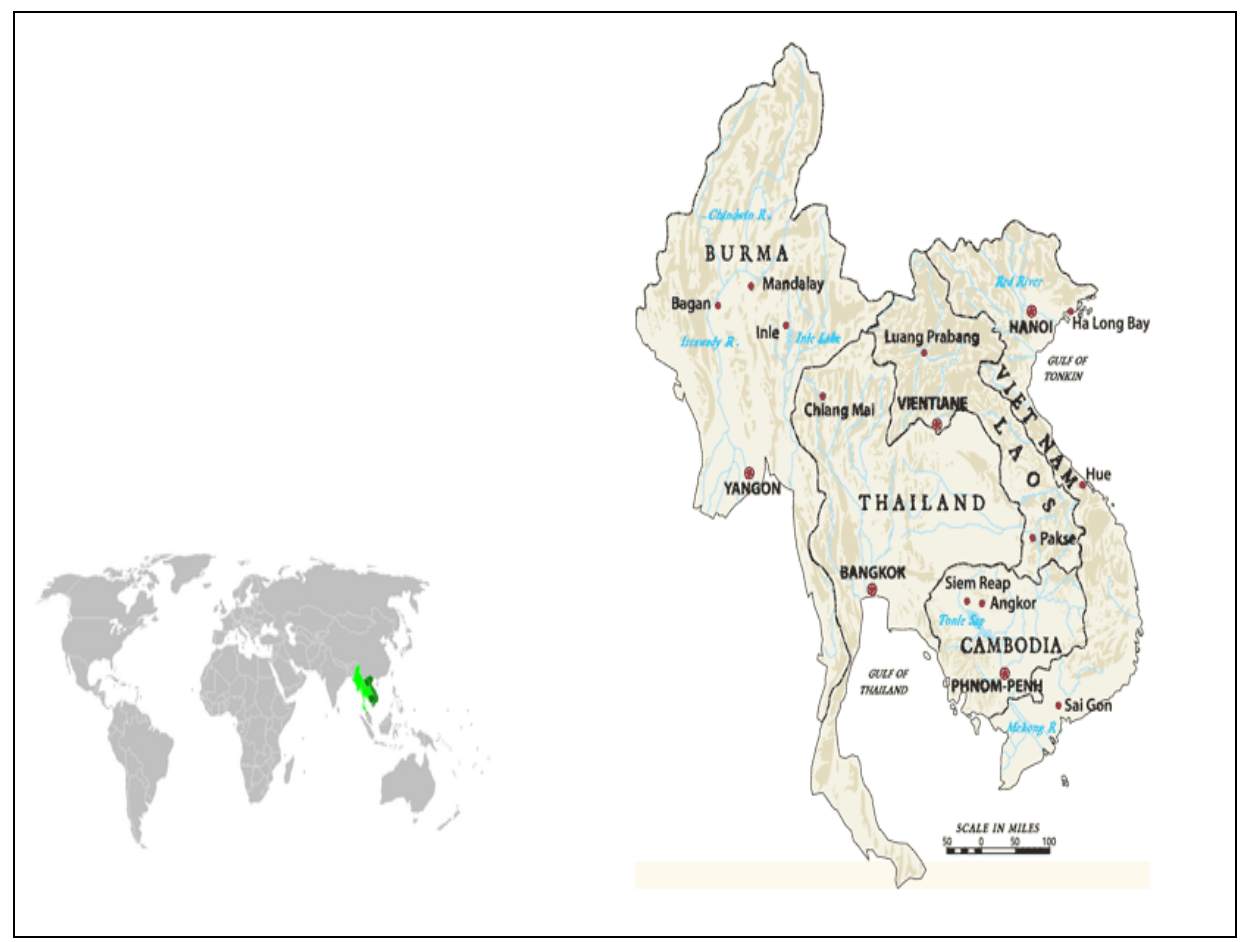

Fig. 3 Map of Indochina [6]

About diversity of primates, Vietnam has 6 primate genera and 24 primate taxa, of which has six endemic taxa (Con Dao long-tailed macaque Macaca fascicularis condorensis, Cat Ba langur T. poliocephalus poliocephalus, Delacour's langur Trachypithecus delacouri, Eastern black gibbon Nomascus nasutus, Greyshanked douclangur Pygathrix cinerea, and Tonkin snub-nosed monkey Rhinopithecus avunculus), and five endemic species and six taxa are listed as "Critically Endangered" and face a very high risk of extinction [34]. However, most, if not all populations are already highly fragmented by the wildlife trade and habitat destruction [34], and gibbons are also listed in these trends

Vietnam has 6 gibbons (Eastern black gibbon Nomascus nasutus, Northern white-cheeked gibbon Nomascus leucogenys, Northern yellow-cheeked gibbon Nomascus annamensis, Southern yellow-cheeked gibbon Nomascus gabriellae, and Western black gibbon Nomascus concolor [12]. Most species of gibbons belongs to genus Nomascus, known as the Crested gibbons. They are distributed from the north to the south of Vietnam (Fig. 1 and Fig. 2). However, Northern white-cheeked gibbon is mainly distributed in the northern of Vietnam (Fig. 2 and Fig. 4).

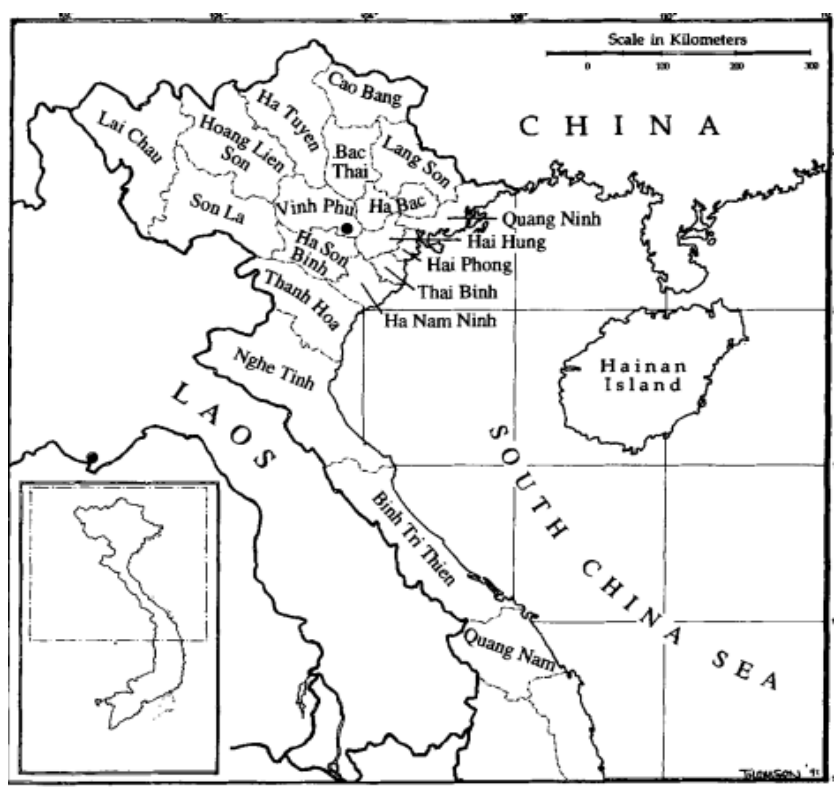

Fig. 4 Provinces in the northern of Vietnam [35] 


\subsection{Threat status of Northern white-cheeked gibbon}

Today, mostly species of the family Hylobatidae are on the brink of extinction, exception of Eastern Hoolock gibbon (Hoolock leuconedys), and are classified as "Endangered" or even "Critically Endangered" ([11], [15]).

According to IUCN, the northern white-cheeked gibbon is currently listed the IUCN Red List of Threatened Species as "Critically Endangered" with A2cd $+3 \mathrm{~cd}$ ver 3.1 [15]. It means that the best available evidence indicates any of the criteria A to E belong to Critically Endangered, the population of N. leucogenys is considered to be facing an extremely high risk of extinction in the wild. In addition, Critically Endangered shows the species has declined by at least $80 \%$ over the part 45 years (three generations) due to habitat loss and hunting [15].

Moreover, Nomascus leucogenys is dealing with threats in the wild. In 2000, Nomascus leucogenys is classified as "Endangered". However, they are listed the IUCN Red list of Threatened Species as "Critically Endangered" since 2008 to now [15].

In addition, Northern white-cheeked gibbon is currently, one of 55 species of primates, listed in the Appendix I of CITES [4]. This means that, they are in danger of extinction, and the highest requiring need for protection, and of which trade is permitted only in exceptional situation (scientific or educational reasons) [3].

Information about the population number of gibbons, Nomascus leucogenys has not been recorded fully the total number of species on Earth. After all, the northern white-cheeked gibbons with less than 500 individuals left in the wild [20].

Although gibbons are listed as either "Critically Endangered" or "Endangered" on the IUCN Red List of Threatened Species in the world [15]. However, the northern white-cheeked gibbons as well as all species of gibbons in Vietnam are listed under the category "Endangered" according to The Red Data Book of Vietnam with the criteria A1 cd C2a [46]. The status shows that they have been a 50\% decline and severe fragmentation of habitat and the population is facing a very high risk of extinction in the wild.

\subsection{The population status and distribution of Northern white-cheeked gibbon}

Northern white-cheeked gibbon is found in the northern of Vietnam ([5], [35]), especially in Hoa Binh Province, Lai Chau Province, Thanh Hoa Province, and Nghe An Province (Table 1; Fig. 4; Fig. 5) [35]. The population of N. leucogenys estimated about 600-800 individuals before 1970 [29]. In addition, the species occurs also in the north-western part of the country and to the west of the Black River [10].

Table 1 Distribution of N. leucogenys in Vietnam before 1992

\begin{tabular}{ccc}
\hline Area/Province & Locality & Coordinates \\
\hline Hoa Binh (Ha Son Binh/Hoa Binh) & Chi Ne & $20^{0} 29^{\prime} \mathrm{N}, 105^{\circ} 47^{\prime} \mathrm{E}$ \\
Lai Chau (Lai Chau) & Muong Lay & $21^{0} 58^{\prime} \mathrm{N}, 103^{0} 09^{\prime} \mathrm{E}$ \\
Thanh Hoa (Thanh Hoa) & Quan Hoa & $20^{0} 36^{\prime} \mathrm{N}, 104^{0} 30^{\prime} \mathrm{E}$ \\
Thanh Hoa (Thanh Hoa) & Bai Thuong & $19^{0} 52^{\prime} \mathrm{N}, 105^{0} 26^{\prime} \mathrm{E}$ \\
Nghe An (Nghe Tinh) & Quy Chau & $19^{0} 33^{\prime} \mathrm{N}, 105^{\circ} 06^{\prime} \mathrm{E}$ \\
\hline
\end{tabular}

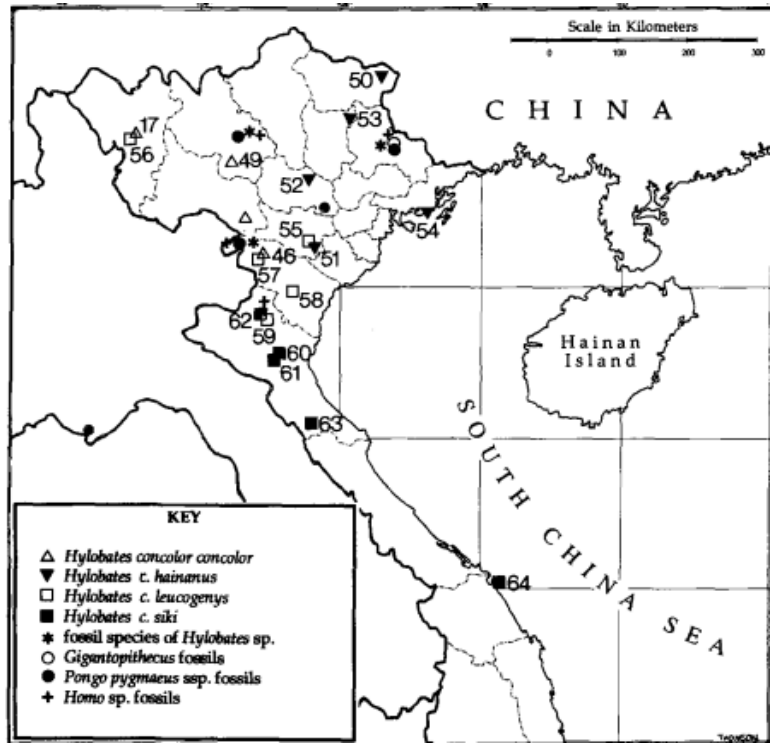

Fig. 5 Distribution of Gibbons in Northern Vietnam before 1992 [35] 
Since 2000, the population of the northern white-cheeked gibbons is recognized in large sites in the northern of Vietnam. Currently, Nomascus leucogenys has been confirmed with less 80 groups in 18 areas of Northern Vietnam (Table 2 and Fig. 6).

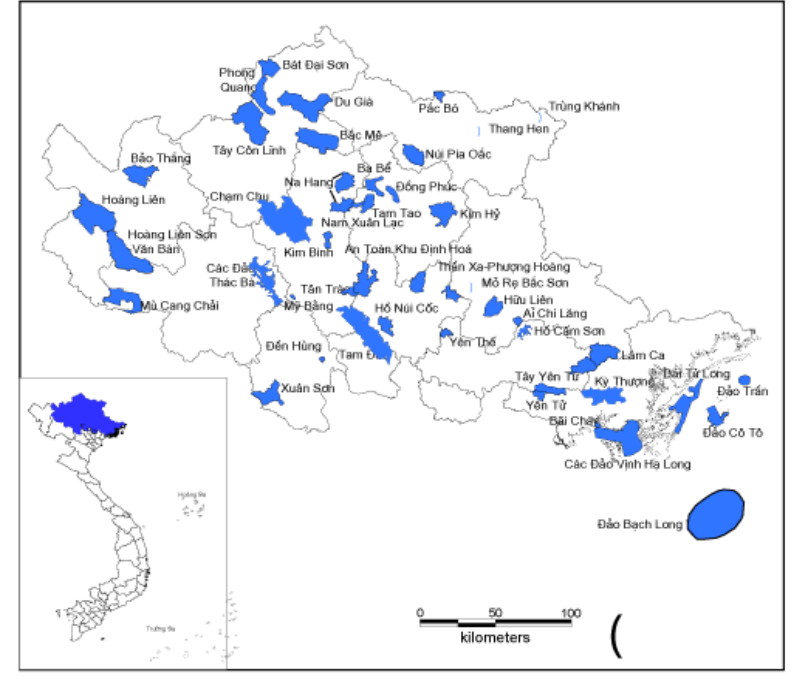

Fig. 6.1 Protected areas in North Eastern (Bac Kan, Bac Giang, Bac Ninh, Cao Bang, Ha Giang, Lang Son, Lao Cai, Phu Tho, Quang Ninh, Thai Nguyen, Tuyen Quang, Vinh Phuc, Yen Bai)

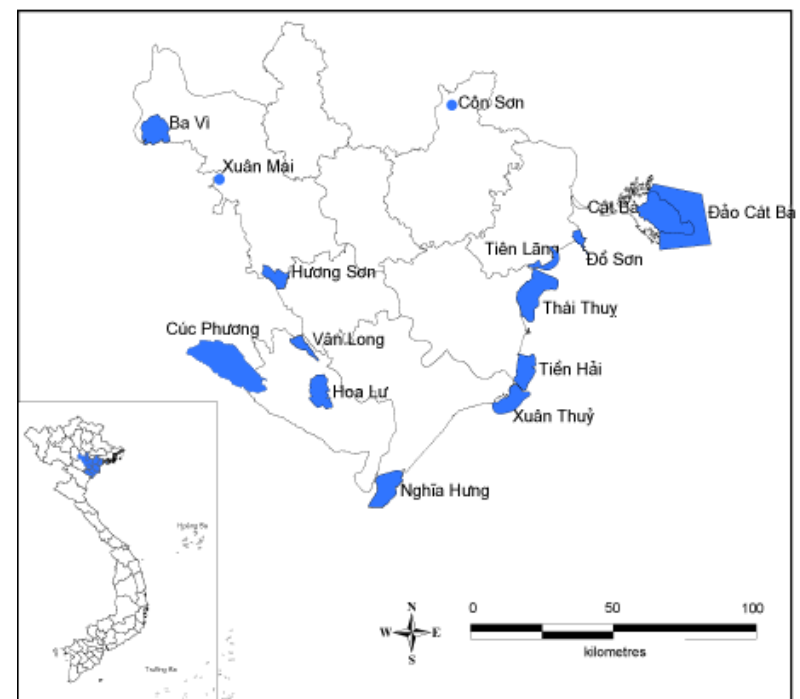

Fig. 6.3 Protected areas in Red River Delta (Ha Noi, Ha Nam, Hai Phong, Hai Duong, Hung Yen, Nam Dinh, Ninh Binh, Thai Binh)

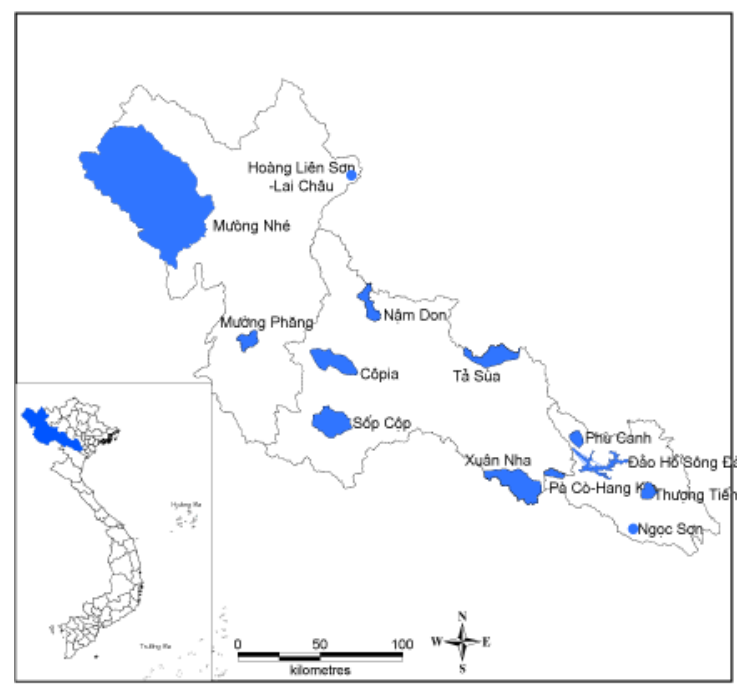

Fig. 6.2 Protected areas in North Western (Lai Chau, Son La, Hoa Binh)

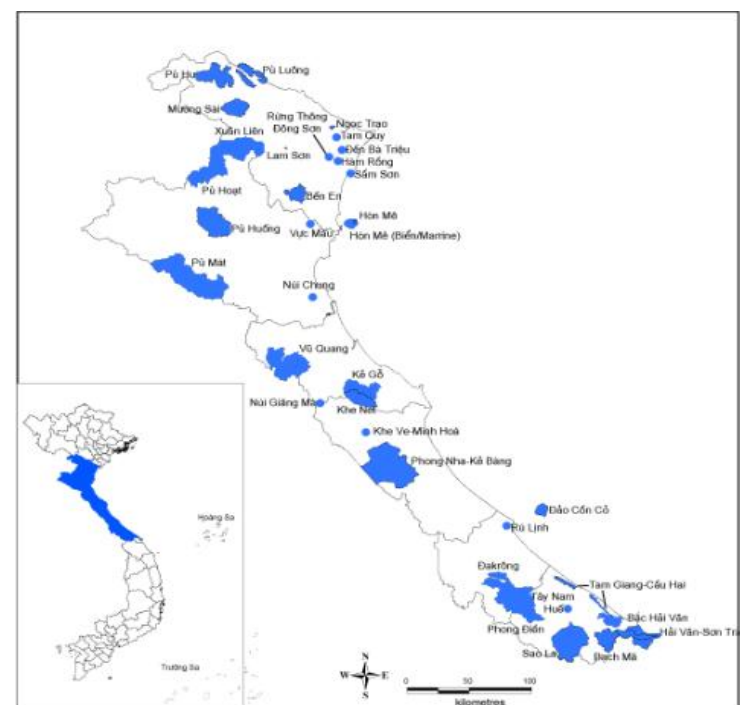

Fig. 6.4 Protected areas in North Central Coast (Thanh Hoa, Nghe An, Ha Tinh, Quang Binh, Quang Tri, Thua Thien Hue)

Fig. 6 Protected areas in Northern Vietnam [1]

Table 2 Distribution of $\mathrm{N}$. leucogenys records in Vietnam since 2000

\begin{tabular}{|c|c|c|c|c|}
\hline Sites & Locations & $\begin{array}{l}\text { Areas } \\
(h a)\end{array}$ & $\begin{array}{l}\text { Populations } \\
\text { (groups) }\end{array}$ & References \\
\hline $\begin{array}{l}\text { Ben En National } \\
\text { Park }\end{array}$ & $\begin{array}{l}\text { Nhu Thanh and Nhu Xuan } \\
\text { Districts, Thanh Hoa } \\
\text { Province }\end{array}$ & 15,800 & $\begin{array}{l}\text { Status unclear; possibly } \\
\text { extirpated }\end{array}$ & [10], [48] \\
\hline $\begin{array}{l}\text { Hang Kia-Pa Co } \\
\text { Nature Reserve }\end{array}$ & $\begin{array}{l}\text { Mai Chau District, Hoa Binh } \\
\text { Province }\end{array}$ & 7,091 & Provisionally extirpated & [17] \\
\hline Huong Son Forest & Huong Son District, Ha Tinh & 30,000 & $\geq 3$ & [36], [40] \\
\hline
\end{tabular}




\begin{tabular}{|c|c|c|c|c|}
\hline & Province & & & \\
\hline $\begin{array}{l}\text { Ke Go Natural } \\
\text { Reserve }\end{array}$ & $\begin{array}{l}\text { Huong Khe, Can Xuyen and } \\
\text { Ky Anh Districts, Ha Tinh } \\
\text { Province }\end{array}$ & 21,759 & $\begin{array}{l}4 \text { groups }(\geq 8 \\
\text { individuals) }\end{array}$ & {$[51]$} \\
\hline $\begin{array}{l}\text { Khe Net Proposed } \\
\text { Nature Reserve }\end{array}$ & $\begin{array}{l}\text { Tuyen Hoa District, Quang } \\
\text { Binh Province }\end{array}$ & 23,534 & Provisionally extirpated & [19], [36], [51] \\
\hline $\begin{array}{l}\text { Long Luong } \\
\text { Commune/ west of } \\
\text { the Black River }\end{array}$ & $\begin{array}{l}\text { Moc Chau District, Son La } \\
\text { Province }\end{array}$ & 5,080 & 2 & [22] \\
\hline $\begin{array}{l}\text { Muong Nhe } \\
\text { Nature Reserve }\end{array}$ & $\begin{array}{l}\text { Muong Nhe District, Dien } \\
\text { Bien Province }\end{array}$ & 45,581 & $\geq 16$ & [38] \\
\hline $\begin{array}{l}\text { Ngoc Son-Ngo } \\
\text { Luong Nature } \\
\text { Reserve }\end{array}$ & $\begin{array}{l}\text { Tan Lac and Vu Ban } \\
\text { Districts, Hoa Binh Province }\end{array}$ & 19,254 & Provisionally extirpated & [18] \\
\hline $\begin{array}{l}\text { Pu Hoat Proposed } \\
\text { Nature Reserve }\end{array}$ & $\begin{array}{l}\text { Que Phong District, Nghe } \\
\text { An Province }\end{array}$ & 35,000 & $\geq 7$ & {$[24],[36]$} \\
\hline $\begin{array}{l}\text { Pu Hu Nature } \\
\text { Reserver }\end{array}$ & $\begin{array}{l}\text { Quan Hoa, Quan Son and } \\
\text { Muong Lat Districts, Thanh } \\
\text { Hoa Province }\end{array}$ & 27,503 & $\begin{array}{l}\text { Unknown; possibly } \\
\text { extirpated }\end{array}$ & {$[36]$} \\
\hline $\begin{array}{l}\text { Pu Huong Nature } \\
\text { Reserve }\end{array}$ & $\begin{array}{l}\text { Que Phong, Quy Chau, Quy } \\
\text { Hop, Con Cuong and Tuong } \\
\text { Districts, Nghe An Province }\end{array}$ & 50,075 & $\geq 7-8$ groups & [23] \\
\hline $\begin{array}{l}\text { Pu Luong Nature } \\
\text { Reserve }\end{array}$ & $\begin{array}{lcr}\text { Quan Hoa } & \text { and Ba } & \text { Thuoc } \\
\text { Districts, } & \text { Thanh } & \text { Hoa } \\
\text { Province } & & \end{array}$ & 17,662 & Extirpated & {$[21],[33]$} \\
\hline $\begin{array}{l}\text { Pu Mat National } \\
\text { Park }\end{array}$ & $\begin{array}{l}\text { Anh Son, Con Cuong and } \\
\text { Tuong Duong Districts, } \\
\text { Nghe An Province }\end{array}$ & 91,113 & $\begin{array}{l}22 \text { groups confirmed, } \\
130 \text { groups estimated }\end{array}$ & {$[25]$} \\
\hline $\begin{array}{l}\text { Sop Cop Nature } \\
\text { Reserve }\end{array}$ & $\begin{array}{l}\text { Sop Cop and Song Ma } \\
\text { Districts, Son La Province }\end{array}$ & 18,709 & $\begin{array}{l}\geq 2 \text { groups (one group } \\
\text { of 3-4 individuals) }\end{array}$ & [39] \\
\hline $\begin{array}{l}\text { Thach Tuong } \\
\text { Commune }\end{array}$ & $\begin{array}{l}\text { Thach Tuong, Thach Thanh } \\
\text { Districts, Thanh Hoa } \\
\text { Province }\end{array}$ & 3,797 & Unknown & {$[10]$} \\
\hline $\begin{array}{l}\text { Vu Quang } \\
\text { National Park }\end{array}$ & $\begin{array}{l}\text { Vu Quang, Huong Son and } \\
\text { Huong Khe Districts, Ha } \\
\text { Tinh Province }\end{array}$ & 56,915 & $\geq 10$ & {$[40]$} \\
\hline $\begin{array}{l}\text { Xuan Lien Nature } \\
\text { Reserve }\end{array}$ & $\begin{array}{l}\text { Thuong Xuan and Nhu Xuan } \\
\text { Districts, Thanh Hoa } \\
\text { Province }\end{array}$ & 27,668 & $\geq 7$ & [16] \\
\hline $\begin{array}{l}\text { Xuan Nha Nature } \\
\text { Reserve }\end{array}$ & $\begin{array}{l}\text { Moc Chau District, Son La } \\
\text { Province }\end{array}$ & 16,317 & $\begin{array}{l}\text { Provisionally extirpated } \\
\text { (group persist in the } \\
\text { buffer zone) }\end{array}$ & [39] \\
\hline
\end{tabular}

Table 2 showed that Pu Mat National has the higher population of Nomascus leucogenys than other areas in Vietnam, with 22 groups confirmed and estimated 130 groups consisting of 455 individuals [25]. Thus, Pu Mat National Park may be considered a key in conservation of N. leucogenys in Vietnam.

Meanwhile, statuses of Nomascus leucogenys fully are unknown in China, because the population may be on the edge of extinction in the wild [9]. Besides, the population of $\mathrm{N}$. leucogenys in Lao PDR is not yet evidently detailed about the population number. However, Lao PDR, in some areas of large forests such as Phou Den Din National Biodiversity Conservation Area, may hold the largest remaining population of the northern white-cheeked gibbons [8], and about 8-15 groups confirmed by communities in Nam Et-Phou Louey National 
Biodiversity Conservation Area [28]. By the same token, the population status of N. leucogenys in Vietnam may become the key of the natural conservation center of this specie in over the world.

However, Table 1 and Table 2 also showed that the population of Nomascus leucogenys has been strongly declined or possibly extirpated/extirpated in some areas of Northern Vietnam, such as Pu Luong Nature Reserve, Pu Hu Nature Reserver, Thanh Hoa Province. Likewise, some sites appear unclear and unknown status about the surviving of N. leucogenys.

\section{Conservation of Northern White-Cheeked Gibbons In Vietnam \\ 3.1. Threats to conservation of Northern white-cheeked gibbons}

Northern white-cheeked gibbon currently deals with many threats in conservation and management. Mainly threats concentrate in the pet trade and habitat degradation.

The pet trade is clearly factor to threat, standing out from hunting actions. It is easily understandable, the legal trade as well as the illegal trade show a serious threat to the survival of many species of wild species. In Vietnam, from 1991 to 1995, Nomascus spp. has been hunted 851 individuals [7]. Gibbons as well as other species have been considered as goods to supply for domestic and international trade, especially illegal trade. By this mention, illegal hunting with using hunting tools such as gun/shotgun was the most common way to supply and demand. About 10,124 hunting guns were seized in Nghe An Province, Vietnam by the Police during the 1990s [37]. Besides, many households live in and around the protected areas, own guns, as an example at Muong Nhe Nature Reserve [38]. Indeed, increasing in illegal trade and hunting will lead many species to the brink of extinction.

In addition, habitat loss is also caused to threat habitat of Nomascus leucogenys in conservation actions. In fact, destruction and fragmentation of habitat have negatively impacts of the population decrease, such as timber logging and non-timber forest products collection, changes of use within agriculture, unsustainable livelihoods. Furthermore, local communities, usually ethnic minority communities, also live in and around the protected areas, which are recognized the population of N. leucogenys. Meanwhile, their livelihoods depend mainly on forests with traditionally practiced forms of shifting cultivation. For example, $\mathrm{Pu}$ Mat National Park has above 88,000 peoples (mainly ethnic minority peoples) within 111 small villages [41], and they live around the core and buffer zones of the protected area. Thus, management and conservation of the natural resources in the protected areas as well as the population of the northern white-cheeked gibbons have many disadvantages and difficulties.

\subsection{Conservation actions in Vietnam}

All gibbons as well as the northern white-cheeked gibbons in Vietnam receive as protected priority species through establishing policies, protected areas to management and conservation of fauna and flora by the Government of Vietnam. According to IUCN, Vietnam has been established 164 special use forests (30 National parks, 69 Nature reserves, 45 Landscape protected areas and 20 Scientific and Experimental forest areas) and 15 proposed Marine Protected Areas of which 6 are officially gazette and 68 Wetland sites [14]. Furthermore, Vietnam also evaluates biodiversity by key areas. It is understandable, all important habitat ecosystems, threatened fauna and flora species are found in these protected areas, which are the places reserving biodiversity and gene resources.

Besides, Vietnam also promulgated Decree No. 32/2006/ND-CP on Management of Endangered, Precious and Rare Forest Plants and Animals by the Government on March 30, 2006. The Decree classifies and defines the conservation level for protected wild animals and plants with two group, I (Forest plants (A) and animals (B) banned from exploitation and use for commercial purposes) and II (Forest plants (A) and animals (B) restricted from exploitation and use for commercial purposes). Then, Northern white-cheeked gibbon is, one of 17 species of primates of mammals, classified under group IB [45].

Based on the Decree No. 32/2006/ND-CP, in 2007, Vietnam has been updated the list species to 2007 Red Data Book of Vietnam. Then, Nomascus leucogenys is listed in Red Data Book of Vietnam under the category Endangered A1 cd C2a due to habitat changing, forest destruction, primary forest narrowed as well as hunting [46].

In addition, thanks to the aware of the importance of biodiversity values and its potential contribution to national economic development, Vietnam joined the Convention on International Trade in Endangered Species of Wild Fauna and Flora (CITES) (1994) and Convention on Biological Diversity (CBD) (1994).

Generally, Vietnam has been established wholly legal documents about biodiversity, natural resources and environmental management. For examples, Law on Forest Protection and Development in 1991 and amended in 2004; Law on Land in 1993 and amended in 2005; Law on Protection of the Environment in 1993 and amended in 2005; Fishery Law in 1989 and amended in 2003; and Biodiversity Law in 2008. Moreover, Vietnam has been approved many strategies and programs relating to conservation actions, which has reflected the commitment of Vietnam's Government in conservation and management actions of the natural resources 
and biodiversity, such as the National Strategy for Environmental Protection (2003), the National Action Plan on Biodiversity $(1995,2007)$. Mostly action plans and strategies show that wild plants and animals are nationally property, which need to be protected in the sustainable development.

\section{Conclusion}

Vietnam owns 6 varieties of gibbons, including Northern white-cheeked gibbons. The population distribution of Northern white-cheeked gibbons, trends to pervading to north of the country with 18 areas, and has less 80 groups confirmed. Meanwhile, Pu Mat National Park should be considered as a main key in conservation of gibbons with higher population of Nomascus leucogenys. Comparing between recognized areas about distribution of $\mathrm{N}$. leucogenys shows that the population trends changing to decreasing in some areas, where they even are unclear/unknown status, either on brink of extinction or extirpation in the wild. In addition, the population status of $\mathrm{N}$. leucogenys deals with many disadvantageous impacts, especially the pet trade within hunting and habitat degradation. Thus, this research aims to further description about negative evaluation as well as improvable habitat in surviving of $\mathrm{N}$. leucogenys, and heads to sustainable manner through efforts at the national and international levels.

Based on the threats to conservation and management of the northern white-cheeked gibbons, the research proposes improvements to communities' livelihoods, especially ethic minority communities live in core and buffer zones of protected areas. The approach can gain through programs and projects to improve livelihoods by stakeholders. Therefore, local communities will reduce their strong dependence on forests, and promote to sustainable livelihoods with forests. Besides, awareness improvement in wildlife production using as well as awareness of roles in biodiversity conservation processing are very important and absolutely signified. In brief, Vietnam needs to establish strategies and national action plan for conservation of gibbons.

In the future, Vietnam, status and habitat of Northern white-cheeked gibbon are better maintained and protected, might become the key of the natural conservation center for the species survival in the world.

The research is as an essential part of population assessments of Nomascus leucogenys as well as status of gibbons in Vietnam. It is hoped that these results will contribute to management and propose suggestions to completely sustainable conservation processing of Vietnam's gibbons. Further, information will help to continuing the next research and trends to detail in better suggestion strategies of management and conservation of gibbons for each areas in Vietnam.

\section{References}

[1] Birdlife International in Indochina and the Forest Inventory and Planning Institute of the Ministry of Agriculture and Rural Development (MARD). 2012. Sourcebook of Existing and Proposed Protected Areas in Vietnam: Second Edition. http://birdlifeindochina.org/. Accessed on October 2012.

[2] Bleisch B., Geissmann T., Manh H.N., Rawson B. and Timmins R.J. 2008. Nomascus leucogenys. In: IUCN 2008. IUCN Red List of Threatened Species.

[3] CITES. 1973. Convention on International Trade in of Wild Fauna and Flora. Signed at Washington, D.C., on 3 March 1973. Amended at Bonn, on 22 June 1979.

[4] CITES. 2012. Appendices I, II and III, valid from 25 September 2012. http://www.cites.org/. Accessed on October 2012.

[5] Dao Van Tien. 1983. On the North Indochinese gibbons (Hylobates concolor) (Primates: Hylobatidae) in North Vietnam. Journal of Human Evolution 12: 367-372.

[6] Discovery Indochina. 2012. Map of Indochina. http://www.discoveryindochina.com/. Accessed on October 2012.

[7] Do T. 1997. Report on wildlife trade in Vietnam. Vietnam life and environment. Political Publishing House, Hanoi, Vietnam.

[8] Duckworth J.W. 2008. Preliminary gibbon status review for Lao PDR 2008. Fauna \& Flora International Indochina Programme. Vientiane, Laos.

[9] Fan P.F and Huo S. 2009. The northern white-cheeked gibbon (Nomascus leucogenys) is on the edge of extinction in China. Gibbon Journal 5: 44-52.

[10] Geissmann T., Nguyen Xuan Dang, Lormee N., Momberg F. 2000. Vietnam primate conservation status review 2000 - Part I: Gibbons. Fauna \& Flora International Indochina Programme. Hanoi, Vietnam.

[11] Geissmann T. 2007. Status reassessment of the gibbons: results of the Asian primate red list workshop 2006. Gibbon Journal 3: 515.

[12] Groves P.C. 2007. Speciation and biogeography of Vietnam's primates. Vietnamese Journal of Primatology 1: 27-40.

[13] Harding L.E. 2012. Nomascus leucogenys (Primates: Hylobatidae). Mammalian Species 44 (890): 1 - 15.

[14] IUCN. 2008. Guidelines for Applying Protected Area Management Categories: Experiences and lessons. IUCN Vietnam. Hanoi, Vietnam.

[15] IUCN. 2012. IUCN Red List of Threatened Species. Version 2012.2. www.iucnredlist.org/. Accessed on October 2012.

[16] Le Huu Oanh and Rawson B.M. 2007. Surveys in Xuan Lien Nature Reserve for the critically endangered northern white-cheeked crested gibbon. Education for Nature and Conservation International, Hanoi, Vietnam.

[17] Le Khac Quyet and Luu Tuong Bach. 2009. Results of wildlife survey in Hang Kia-Pa Co Nature Reserve, Mai Chau District, Hoa Binh Province. Center for People and Nature Reconciliation, Hanoi, Vietnam.

[18] Le Trong Dat, Do Quang Huy, Le Thien Duc, Luu Quang Vinh and Luong Van Hao. 2008. Survey report on vertebrate fauna of Ngoc Son-Ngo Luong Nature Reserve, Tan Lac, Vu Ban district, Hoa Binh province, Vietnam. Ngoc Son-Ngo Luong Project/Forest Protection Department Hoa Binh province and Foundation for Social Promotion on Culture, Spain, Hanoi, Vietnam.

[19] Le Trong Trai, Tran Hieu Minh and Do Tuoc. 2001. Feasability study for the establishment of Khe Net Nature Reserve, Quang Binh Province, Vietnam. BirdLife International Vietnam Programme and the Forest Inventory and Planning Institute, Hanoi, Vietnam. 
[20] Lucia Carbone, Mootnick A.R., Tilo Nadler, Pierre Moisson, Oliver Ryder, Christian Roos, Pieter J. 2009. A Chromosomal Inversion Unique to the Northern White-Cheeked Gibbon. PLoS ONE 4 (3): e4999.

[21] Luong Van Hao and Le Van Hai. 2008. Results of a survey and estimate of the status of Delacour's langur (Trachypithecus delacouri) in Pu Luong Nature Reserve. Thanh Hoa Forest Protection Department, Pu Luong Nature Reserve, Pu Luong, Vietnam.

[22] Luu Tuong Bach and Nguyen Van Truong. 2011. Short survey on gibbons in Long Luong Commune, Moc Chau District, Son La Province. Conservation International and Fauna \& Flora International, Hanoi, Vietnam.

[23] Luu Tuong Bach and Rawson B. 2009. As assessment of northern white-cheeked crested gibbon (Nomascus leucogenys) population status in Pu Huong Nature Reserve, Nghe An Province, Vietnam. Conservation International, Hanoi, Vietnam.

[24] Luu Tuong Bach and Rawson B. 2010. An assessment of the status of the northern white-cheeked crested gibbon (Nomascus leucogenys) in Pu Hoat Proposed Nature Reserve, Que Phong District, Nghe An Province, Vietnam. Conservation International, Hanoi, Vietnam.

[25] Luu Tuong Bach and Rawson B. 2011. Population assessment of the northern white-cheeked crested gibbon (Nomascus leucogenys) in Pu Mat National Park, Nghe An Province. Conservation International and Fauna \& Flora International, Hanoi, Vietnam.

[26] Luu Tuong Bach and Nguyen Van Truong. 2011. Short survey on gibbons in Long Luong Commune, Moc Chau District, Son La Province. Conservation International and Fauna \& Flora International, Hanoi, Vietnam.

[27] Meyer T.J., McLain A.T, Oldenburg J.M., Faulk C., Bourgeois M.G., Conlin E.M., Mootnick A.R, Jong P.J., Roos C., Carbone L. and Batzer M.A. 2012. An Alu-based phylogeny of gibbons (Hylobatidae). Molecular Biology and Evolution 29: 3441-3450

[28] Ministry of Agriculture and Forest. 2011. Gibbon Conservation Action Plan for Lao PDR 2011 to 2020. Division of Forest Resource Consrvation, Department of Forestry. Vientiane, Lao PRD.

[29] Ministry of Natural Resources and Environment. 2005. National Environment Report. Hanoi, Vietnam.

[30] Ministry of Natural Resources and Environment. 2008. The fourth country report Vietnam's implementation of the biodiversity convention. Hanoi, Vietnam.

[31] Mootnick A.R. 2006. Gibbon (Hylobatidae) species identification recommended for rescue or breeding centers. Primate Conservation 21: 103-138.

[32] Mootnick A.R and Fan P.F. 2011. A comparative study of crested gibbons (Nomascus). American Journal of Primatology 73: 135154.

[33] Nadler T., Le Trong Dat and Luong Van Hao. 2004. A primate field survey at Pu Luong Nature Reserve with the emphasis on Delacour's langur (Trachypithecus delacouri). Fauna \& Flora International Vietnam Conservation Support Programme, Forest Protection Department and Frankfurt Zoological Society, Hanoi, Vietnam.

[34] Nadler T., Vu Ngoc Thanh and Streicher U. 2007. Conservation status of Vietnamese primates. Vietnamese Journal of Primatology 1: 7-26

[35] Nisbett, Richard A., Ciochon and Russell L. 1993. Primates in northern Vietnam: A review of the ecology and conservation status of extant species, with notes on Pleistocene localities. International Journal of Primatology 14: 765-795.

[36] Nguyen Manh Ha. 2005. Status of white cheek-crested gibbon (Nomascus leucogenys) in north central of Vietnam. Center for Natural Resources and Environmental Studies, Hanoi, Vietnam.

[37] Nguyen Manh Ha, Vu Van Dung, Nguyen Van Song, Hoang Van Thang, Nguyen Huu Dung, Pham Ngoc Tuan, Than Thi Hoa and Doan Canh. 2007. Report on the review of Vietnam's wildlife trade policy. CRES/FPD/UNEP/CITES/IUED, Hanoi, Vietnam.

[38] Nguyen Manh Ha, Do Tuoc, Nguyen Quoc Tang, Nguyen Manh Cuong, Le Van Dung and Luu Tuong Bach. 2010. Report of whitecheeked crested gibbon (Nomascus leucogenys) survey in Muong Nhe Nature Reserve, Dien Bien Province, Vietnam. Fauna \& Flora International and Conservation International, Hanoi, Vietnam.

[39] Nguyen Manh Ha, Do Tuoc and Le Van Dung. 2011. A survey of white-cheeked gibbons (Nomascus leucogenys) and large mammals (Mammalia) in Xuan Nha Nature Reserve and Sop Cop Nature Reserve, Son La Province. Centre for Natural Resources and Environmental Studies, Hanoi, Vietnam.

[40] Nguyen Manh Ha, Do Tuoc and Le Van Dung. 2011. A survey of white-cheeked gibbons (Nomascus leucogenys) in Vu Quang National Park and Huong Son Forestry Company, Ha Tinh Province. Centre for Natural Resources and Environmental Studies, Hanoi, Vietnam.

[41] Nguyen Thanh Nhan. 2011. Biodiversity conservation in Pu Mat National Park. Symposium on National Parks and Natural Reserves of Vietnam. Pu Mat National Park, Nghe An Province, Vietnam.

[42] Richard P.C., Wisnewski J. and Engelman R. 2000. Human population in the biodiversity hotspot. Nature 404: 992.

[43] Roos Christian, Vu Ngoc Thanh, Lutz Walter and Tilo Nadler. 2007. Molecular systematics of Indochinese primates. Vietnamese Journal of Primatology 1: 41-53.

[44] Rowe N. 1996. The Pictorial Guide to Living Primates. Pogonias Press. East Hampton, New York.

[45] The Government of the Socialist Republic of Vietnam. 2006. Decree No. 32/2006/ND-CP on Management of Endangered, Precious and Rare Forest Plants and Animals. Official Gazette 06-07/Apr. 5/2006: 19-31. Hanoi, Vietnam.

[46] The Red Data Book of Vietnam. 2007. Science and techniques Publishing House. Hanoi, Vietnam.

[47] Thin N.N. 1997. Manual for biodiversity research. Agricultural Publishing House. Hanoi, Vietnam.

[48] Tordoff A., Fanning E. and Grindley M. (Ed.). 2000. Ben En National Park: a biodiversity survey. Society for Environmental Exploration, UK and Institure of Ecology and Biological Resources, Hanoi, Vietnam.

[49] Van Ngoc Thinh, Mootnick A.R., Geissmann T., Ming Li, Ziegler T., Agil M., Moisson P., Nadler T., Walter L., Roos C. 2010. Mitochondrial evidence for multiple radiations in the evolutionary history of small apes. BMC Evolutionary Biology 10: 74.

[50] Van Ngoc Thinh, B. Rawson, C. Hallam, M. Kenyon, T. Nadler, L. Walter, and C. Roos. 2010. Phylogeny and distribution of crested gibbons (genus Nomascus) based on mitochondrial cytochrome b gene sequence data. American Journal of Primatology 72: 1047-1054.

[51] Van Ngoc Thinh, Luong Viet Hung and Nguyen Tien Dung, Roos C. 2010. Population survey of white-cheeked crested gibbons in Ke Go Nature Reserve, Ha Tinh Province, and Khe Net Proposed Nature Reserve, Quang Binh Province. Fauna \& Flora International, Conservation International \& German Primate Centre, Hanoi, Vietnam.

[52] World Conservation Monitoring Centre. 1992. Development of a national biodiversity index: A discussion paper prepared by the World Conservation Monitoring Centre. Cambridge, UK. 